\title{
Coefficients of Real Estate Tax: Case Study of the Czech Republic
}

\author{
Gabriela KUKALOVÁ, Daniela PFEIFEROVÁ, Ivana KUCHǍ̌OVÁ*, \\ Olga REGNEROVÁ and Dana ŠTURMOVÁ
}

Czech University of Life Sciences Prague, Prague, Czech Republic; kukalova@pef.czu.cz; pfeiferova@pef.czu.cz; kucharovai@pef.czu.cz; oregnerova@pef.czu.cz; danasturmova@seznam.cz

* Corresponding author: kucharovai@pef.czu.cz

\begin{abstract}
The paper focuses on the use of the possible potential of real estate tax revenues by municipalities in the Czech Republic. Municipalities can set or adjust the rate of coefficients for real estate tax. The objective of the paper is to evaluate how municipalities in the Czech Republic use the possibility of introducing or adjusting real estate tax coefficients, and then determine the potential for possible revenues from this tax. The evaluation of revenues from real estate tax is performed for the period 2016-2018. The data were provided by the Financial Administration of the Czech Republic. The coefficient 1.5 was used in the analyzed period by $8-24 \%$ of municipalities depending on the type of real estate, the local coefficient was used by more than $9 \%$ of municipalities. The potential revenue from real estate tax was determined in three model cases on the basis of data for 2018. If all municipalities in the Czech Republic set both coefficients, revenue from real estate tax would increase by CZK 54.3 billion to CZK 62.1 billion per year. The share of real estate tax revenue in municipal tax revenues would increase from $4.76 \%$ to $27.45 \%$.
\end{abstract}

Keywords: real estate tax; municipality; coefficient; yield; revenue; Czech Republic

\section{JEL Classification: $\mathrm{H7}$}

\section{Introduction}

Tax revenues play a key role in financing the expenditure side of municipal budgets. The overall economic downturn and other negative impacts related to COVID 19 will affect the level of this revenue. Therefore, their specific composition will be important for municipalities. As stated in her paper Kukalová et al. (2019), from the point of view of management and development of municipalities and regions, it is important to know the basic principles of financing, financial management and also the redistribution of tax revenues.

Tax revenues and subsidy programs play a crucial role on the revenue side of municipal budgets. Revenues from land taxation generate revenue for city budgets in more or less all EU countries. Land taxation can also be linked to the tax autonomy of municipalities in connection with the redistribution of public resources Janoušková and Sobotovičová (2019). The influence of the tax burden on investments is reported by Moravec and Kukalová (2014). 
Among other things, their study addresses the impact of the direct tax burden, which includes real estate tax, on investment allocation.

According to Drabek (2015), the implementation of a conscious tax policy for real estate taxes is a basic condition for the autonomy and financial self-sufficiency of the municipality. In his contribution, he solves the problem of the municipal strategy in relation to the determination of real estate tax rates. Correct determination of the real estate tax base according to research Źróbek et al. (2016), also affects the size of the revenue from this tax. Cammeraat and Crivelli (2020) also point out the importance of a proper consideration of all the factors that affect real estate tax revenue in Italy. Makovská et al. (2020) discusses the possible dependence of the size of the real estate tax rate and the local political cycle in selected municipalities in Poland. Polish municipalities have more freedom in formulating real estate rates than Czech municipalities Olejniczak et al. (2020). Blazic et al. (2016) emphasizes the different perception of the effect of the introduction of real estate tax from the perspective of qualified professionals and the general public. The importance of the real estate tax as a stable source for local governments is addressed in the Huang study (2018), following the problems that the collection of this tax brings to China. The real estate tax is a part of the tax system of the Czech Republic and this tax is one of the property taxes. They are of limited importance in the current tax system of the Czech Republic, although property taxes are among the oldest types of taxes and have been the first direct taxes in history to be applied (Vančurová \& Láchová, 2016). The real estate tax in the Czech Republic consists of two partial taxes: land taxes and taxes on buildings and units. For buildings and units and for most plots of land, the tax is levied per unit. The tax base is the acreage of land or builtup or floor space.

The entire revenue from this tax goes to the municipal budget. Therefore, it is important that municipalities can, within their partial tax jurisdiction, influence the total amount of funds that will become part of the municipal budget by adjusting the basic rates of both land tax and taxes on buildings and units Pfeiferová et al. (2020). According to the Czechia (1992) $\S 6$ par. 4 let. b) and $\S 11$ par. 3 let. a), the municipality has the possibility to increase or decrease the coefficient by which the basic tax rate is multiplied (coefficient assigned to municipalities according to the number of inhabitants). Furthermore, according to the Czechia (1992) for specific taxable buildings defined in $\S 11$ par. b) to d) and units according to $\S 11$ par. 1 let. c) and d), the municipality may introduce a coefficient of 1.5 , which multiplies the basic tax rate (coefficient 1.5). Furthermore, self-governing units may set a coefficient pursuant to Section 12 of Act No. 338/1992 Coll. (local coefficient). This is a coefficient of 2,3,4, or 5, which allows to increase the tax liability for real estate in this cadastral area (Czechia, 1992). The existence of large industrial or recreational areas can also significantly increase the income of individual territorial self-governing units.

As stated in the paper Sedmihradská and Bakoš (2016), only 8\% of municipalities in the Czech Republic use the local coefficient and its determination depends on the political composition of their executive bodies and on the overall structure of budget revenues and expenditures. According to Janoušková and Sobotovičová (2017), the motivation to increase 
COEFFICIENTS OF REAL ESTATE TAX

real estate tax revenues differs mainly in relation to the specific application of individual coefficients. The differences also result from the structure of buildings and land in the municipality and the way they are used. Some municipalities are introducing coefficients for increasing the taxation of buildings for family recreation, while others want to burden buildings for business with higher taxes Janoušková and Sobotovičová (2017). The relationship between real estate tax revenue and the introduction of a local coefficient for municipalities in the Czech Republic is also addressed in his contribution by Bečica (2014), according to which its use in statutory cities in the Czech Republic is insufficient. As determined by Pfeiferová et al. (2020), regional cities use coefficients for adjusting real estate tax revenue to a greater extent than other municipalities.

As stated in the mentioned studies, increasing real estate tax coefficients can serve as an alternative to strengthening the financial self-sufficiency of municipalities. The aim of thethe research is to evaluate how municipalities in the Czech Republic use the possibility of introducing or adjusting real estate tax coefficients. The main objective is to determine the potential of real estate tax revenues if municipalities use real estate tax coefficients.

Table 1. Prescribed tax by type of real estate A-Z and share in total prescribed tax in 2016 - 2018, source: Financial Administration (2019), own work

\begin{tabular}{|c|c|c|c|c|c|c|}
\hline \multirow[t]{2}{*}{ Type of real estate } & \multicolumn{2}{|c|}{2016} & \multicolumn{2}{|c|}{2017} & \multicolumn{2}{|c|}{2018} \\
\hline & $\begin{array}{c}\text { Tax } \\
\text { (ths. CZK) }\end{array}$ & $\%$ & $\begin{array}{c}\text { Tax } \\
\text { (ths. CZK) }\end{array}$ & $\%$ & $\begin{array}{c}\text { Tax } \\
\text { (ths. CZK) }\end{array}$ & $\%$ \\
\hline A farmland & $1,836,431$ & $17.78 \%$ & $1,894,743$ & $17.76 \%$ & $1,914,823$ & $17.76 \%$ \\
\hline B permanent grassland & 99,788 & $0.97 \%$ & 102,966 & $0.97 \%$ & 104,048 & $0.97 \%$ \\
\hline C commercial forest & 189,269 & $1.83 \%$ & 159,265 & $1.49 \%$ & 197,349 & $1.49 \%$ \\
\hline D pond (fish farming) & 1,292 & $0.01 \%$ & 1,419 & $0.01 \%$ & 1,347 & $0.01 \%$ \\
\hline E built-up area and courtyard & 113,198 & $1.10 \%$ & 114,684 & $1.07 \%$ & 118,030 & $1.07 \%$ \\
\hline $\mathrm{F}$ building land & 69,003 & $0.67 \%$ & 69,508 & $0.65 \%$ & 71,948 & $0.65 \%$ \\
\hline G other area & 525,095 & $5.08 \%$ & 557,655 & $5.23 \%$ & 547,510 & $5.23 \%$ \\
\hline$X$ paved area (business in agricult., etc.) & 43,560 & $0.42 \%$ & 46,086 & $0.43 \%$ & 45,420 & $0.43 \%$ \\
\hline Y paved area (other types of business) & 820,956 & $7.95 \%$ & 867,892 & $8.13 \%$ & 856,000 & $8.13 \%$ \\
\hline $\mathrm{H}$ residential building & $1,383,604$ & $13.39 \%$ & $1,424,150$ & $13.35 \%$ & $1,442,666$ & $13.35 \%$ \\
\hline I building - outbildings to $\mathrm{H}$ & 201,047 & $1.95 \%$ & 205,134 & $1.92 \%$ & 209,629 & $1.92 \%$ \\
\hline J cottage & 233,754 & $2.26 \%$ & 237,644 & $2.23 \%$ & 243,732 & $2.23 \%$ \\
\hline K outbildings to J & 18,174 & $0.18 \%$ & 17,901 & $0.17 \%$ & 18,950 & $0.17 \%$ \\
\hline L garage & 237,159 & $2.30 \%$ & 241,768 & $2.27 \%$ & 247,283 & $2.27 \%$ \\
\hline $\mathrm{M}, \mathrm{N}, \mathrm{O}$ building used for business & $3,254,523$ & $31.50 \%$ & $3,395,405$ & $31.82 \%$ & $3,393,449$ & $31.82 \%$ \\
\hline P other taxable construction & 121,014 & $1.17 \%$ & 113,934 & $1.07 \%$ & 126,180 & $1.07 \%$ \\
\hline $\mathrm{R}$ apartment (for living) & $1,038,327$ & $10.05 \%$ & $1,066,202$ & $9.99 \%$ & $1,082,650$ & $9.99 \%$ \\
\hline $\mathrm{S}, \mathrm{T}, \mathrm{U}$ apartment (for business) & 83,040 & $0.80 \%$ & 88,477 & $0.83 \%$ & 86,585 & $0.83 \%$ \\
\hline $\mathrm{V}$ unit used as a garage & 51,006 & $0.49 \%$ & 53,577 & $0.50 \%$ & 53,183 & $0.50 \%$ \\
\hline Z others unit & 10,757 & $0.10 \%$ & 11,591 & $0.11 \%$ & 11,216 & $0.11 \%$ \\
\hline Overall & $10,331,000$ & $100.00 \%$ & $10,670,000$ & $100.00 \%$ & $10,772,000$ & $100.00 \%$ \\
\hline
\end{tabular}




\section{Methodology}

The amount of real estate tax and its development was evaluated for the period 20162018. Data on the amount of prescribed tax and shares in individual types of real estate in the total tax were provided to the Financial Administration of the Czech Republic from the ADIS system (see Table 1 above). The data were provided on the basis of a request pursuant to Act No. 106/1999 Coll., On Free Access to Information.

The evaluation of the use of coefficients was performed on the basis of data provided by the Financial Administration of the Czech Republic (from the ADIS system). The analyzes were focused on a coefficient of 1.5 and a local coefficient. The municipality may set the coefficient 1.5 (C 1.5) by a generally binding decree for selected types of buildings and units (according to $\S 11$ paragraph 3 letter b) of Act No. 338/1992 Coll., On Real Estate Tax). If the municipality determines it, the tax rate is multiplied by this coefficient. The local coefficient (LC) may be set by municipalities by a generally binding decree for selected types of land and for all buildings and units in the amount of 2 or 3 or 4 or 5 for the entire territory of the municipality (according to $\S 12$ of Act No. 338/1992 on real estate). If the municipality sets this coefficient, the tax calculated by it is multiplied.

As part of the analysis focused on C 1.5, buildings and units for which this coefficient can be determined were excluded from the data set. Subsequently, the number of municipalities that had C 1.5 determined in individual years of the analyzed period was determined. The numbers of municipalities had to be determined for each type of buildings and units, because some municipalities use this coefficient only for selected types of buildings and units. Part of the analysis was to determine the share of municipalities that use C 1.5 (for each type of buildings and units) in the total number of municipalities in the Czech Republic.

As part of the analysis focused on the use of the local coefficient, the total number of municipalities that determined the local coefficient was found out. A more detailed analysis was focused on determining the number of municipalities according to the local coefficient set above. Subsequently, the share of municipalities with a set LC in the total number of municipalities in the Czech Republic was determined. The share was also determined in terms of the amount of local coefficient used in individual municipalities. The potential revenue from real estate tax was determined in three model cases (Model 1, Model 2, Model 3). Model 1 presents cases of maximum use of $C 1.5$ by all municipalities in the Czech Republic. The model case is calculated on the assumption that neither the local coefficient nor the coefficient 1.5 is determined, the other coefficients are determined as in 2018. The calculation is performed using the formula:

$$
\text { Potential tax revenue }=\text { Basic tax amount } x \text { C } 1.5
$$

where the basic amount of tax is the amount of prescribed tax adjusted for the coefficient 1.5 and local coefficients set by some municipalities, $C 1.5$ is the coefficient for buildings and units of type J, K, L, M, N, O, S, T, U and V.

Model 2 presents cases of use of individual amounts of LC by all municipalities in the Czech Republic. The model case is calculated on the assumption that neither the local 
coefficient nor the coefficient 1.5 is determined, the other coefficients are determined as in 2018. The calculation is performed using the formula:

$$
\text { Potential tax revenue }=\text { Basic tax amount } x \text { LC }
$$

where the basic amount of tax is the amount of tax prescribed net of a coefficient of 1.5 and local coefficients set by some municipalities, $L C$ is a local coefficient of 2, 3, 4 or 5 for all types of immovable property subject to tax with the exception of land types A and B.

Model 3 presents cases of maximum use of C 1.5 and LC by all municipalities in the Czech Republic. The potential tax revenue is determined based on a combination of calculations under (1) and (2).

The amount of the prescribed real estate tax in 2018 was subsequently compared with the determined revenue potential. The comparison was made as a share of tax and total revenues of municipalities in the Czech Republic. This comparison is made on the basis of data on total revenues and tax revenues of municipalities in the Czech Republic. In 2018, the total revenues of municipalities were 330,860,576 ths. CZK (Czech Statistical Office, 2020). Tax revenues in that year were $226,220,087$ ths. CZK, of which real estate tax revenues amounted to 10,855,672 ths. CZK. This real estate tax revenue also includes amounts paid in tax from previous years, therefore it differs from the prescribed tax for 2018 of $10,772,000$ ths. CZK.

\section{Results}

Municipalities can influence the amount of income from real estate tax by setting coefficients for real estate tax. The analyzes show that municipalities in the Czech Republic use this power only partially. The use of individual coefficients also differs. Real estate tax revenue is low and below potential.

\subsection{Use of Real Estate Tax Coefficients in Czech Municipalities}

The analysis of data provided by the Financial Administration of the Czech Republic (2019) shows that C 1.5 is used by municipalities mainly for type J and K buildings (Table 2). For these types of buildings (recreational building and outbildings), C 1.5 was set by approximately $24 \%$ of municipalities. This coefficient was also often determined by municipalities for buildings used for business ( $M, N, O)$.

The analysis provided by the Financial Administration of the Czech Republic shows that the share of municipalities that use the local coefficient is less than 10 percent (Table 3). If a municipality sets this coefficient, it is most often in the amount of 2. Only 17 municipalities used the local coefficient of 5 in the monitored period (Table 3).

\subsection{Determination of potential income from real estate tax}

On the basis of the share of tax revenues in individual real estate, the potential tax revenue from buildings and units in the case of the use of $C 1.5$ by all municipalities in the Czech Republic was determined. The real estate tax revenue for all relevant types of buildings and units was adjusted for the purposes of the calculation from the coefficients set by some 
COEFFICIENTS OF REAL ESTATE TAX

Table 2. Number of municipalities that used C 1.5 in the period 2016 - 2018 for individual types of buildings and units and share in the total number of municipalities, source: Financial Administration (2019); own work

\begin{tabular}{|c|r|r|r|r|r|r|}
\hline \multirow{2}{*}{$\begin{array}{c}\text { Type of } \\
\text { buildings } \\
\text { and units }\end{array}$} & \multicolumn{2}{|c|}{2016} & \multicolumn{2}{|c|}{2017} & \multicolumn{2}{c|}{2018} \\
\cline { 2 - 7 } & $\begin{array}{c}\text { Number of } \\
\text { municipalities }\end{array}$ & Percentage & $\begin{array}{c}\text { Number of } \\
\text { municipalities }\end{array}$ & Percentage & $\begin{array}{c}\text { Number of } \\
\text { municipalities }\end{array}$ & Percentage \\
\hline $\mathrm{J}$ & 1,485 & $23.73 \%$ & 1,520 & $24.29 \%$ & 1,520 & $24.29 \%$ \\
\hline $\mathrm{K}$ & 1,486 & $23.75 \%$ & 1,520 & $24.29 \%$ & 1,519 & $24.27 \%$ \\
\hline $\mathrm{L}$ & 709 & $11.33 \%$ & 730 & $11.67 \%$ & 731 & $11.68 \%$ \\
\hline $\mathrm{M}$ & 802 & $12.82 \%$ & 823 & $13.15 \%$ & 826 & $13.20 \%$ \\
\hline $\mathrm{N}$ & 881 & $14.08 \%$ & 906 & $14.48 \%$ & 908 & $14.51 \%$ \\
\hline $\mathrm{O}$ & 877 & $14.01 \%$ & 898 & $14.35 \%$ & 901 & $14.40 \%$ \\
\hline $\mathrm{S}$ & 575 & $9.19 \%$ & 596 & $9.52 \%$ & 602 & $9.62 \%$ \\
\hline $\mathrm{T}$ & 606 & $9.68 \%$ & 628 & $10.04 \%$ & 635 & $10.15 \%$ \\
\hline $\mathrm{U}$ & 612 & $9.78 \%$ & 634 & $10.13 \%$ & 642 & $10.26 \%$ \\
\hline $\mathrm{V}$ & 522 & $8.34 \%$ & 545 & $8.71 \%$ & 549 & $8.77 \%$ \\
\hline
\end{tabular}

Table 3. Number of municipalities that used the local coefficient in the period 2016 - 2018 and the share in the total number of municipalities, source: Financial Administration of the Czech Republic (2019); own work

\begin{tabular}{|c|c|c|c|c|c|c|}
\hline \multirow{2}{*}{$\begin{array}{c}\text { Local } \\
\text { coefficient }\end{array}$} & \multicolumn{2}{|c|}{2016} & \multicolumn{2}{c|}{2017} & \multicolumn{2}{c|}{2018} \\
\cline { 2 - 7 } & $\begin{array}{c}\text { Number of } \\
\text { municipalities }\end{array}$ & Percentage & $\begin{array}{c}\text { Number of } \\
\text { municipalities }\end{array}$ & Percentage & $\begin{array}{c}\text { Number of } \\
\text { municipalities }\end{array}$ & Percentage \\
\hline 2 & 482 & $7.70 \%$ & 501 & $8.01 \%$ & 507 & $8.10 \%$ \\
\hline 3 & 63 & $1.01 \%$ & 67 & $1.07 \%$ & 70 & $1.12 \%$ \\
\hline 4 & 11 & $0.18 \%$ & 16 & $0.26 \%$ & 14 & $0.22 \%$ \\
\hline 5 & 17 & $0.27 \%$ & 17 & $0.27 \%$ & 17 & $0.27 \%$ \\
\hline Overall & 573 & $9.16 \%$ & 601 & $9.60 \%$ & 608 & $9.72 \%$ \\
\hline
\end{tabular}

Table 4. Model 1: The potential for tax revenue from buildings and units for 2018, if municipalities make full use of the coefficient of 1.5 (ths. CZK); own calculation

\begin{tabular}{|c|r|r|r|r|}
\hline $\begin{array}{c}\text { Type of building } \\
\text { or unit }\end{array}$ & Prescribed tax & $\begin{array}{r}\text { Revenue without } \\
\text { LC }\end{array}$ & $\begin{array}{c}\text { Revenue without } \\
\text { C } 1.5\end{array}$ & $\begin{array}{c}\text { Revenue with full } \\
\text { use C } 1.5\end{array}$ \\
\hline J & 243,732 & 240,665 & 201,695 & 302,543 \\
\hline K & 18,950 & 18,712 & 15,680 & 23,520 \\
\hline L & 247,283 & 244,171 & 225,156 & $3,377,34,8$ \\
\hline M, N, O & $3,393,449$ & $3,350,742$ & $2,410,164$ & $3,615,246$ \\
\hline P & 126,180 & 124,592 & 126,180 & 126,180 \\
\hline R & $1,082,650$ & $1,069,025$ & $1,069,025$ & $1,069,025$ \\
\hline S, T, U & 86,585 & 85,495 & 68,354 & 102,531 \\
\hline V & 53,183 & 52,514 & 452,670 & 679,005 \\
\hline Overall & $5,252,012$ & $5,185,916$ & $4,568,925$ & $6,255,784$ \\
\hline
\end{tabular}


COEFFICIENTS OF REAL ESTATE TAX

municipalities for selected types of buildings and units. It was found that the potential tax revenue for these types of real estate would increase by approximately CZK 1 billion (Table 4).

In the calculations, the potential for real estate tax revenue was calculated in model cases if all municipalities in the Czech Republic used only the local coefficient. The calculations performed for individual values of local coefficients show that municipalities could achieve a significant increase in real estate tax revenue this way. In the case of determining LC 2, the revenue would amount to more than CZK 19 billion, if all municipalities used LC 5, the total revenue would amount to more than CZK 45 billion (Table 5).

Table 5. Model 2: The potential for tax revenue for 2018, if municipalities use the local coefficient (ths. CZK), own calculation

\begin{tabular}{|c|c|c|c|c|c|c|}
\hline $\begin{array}{c}\text { Type of real } \\
\text { estate }\end{array}$ & $\begin{array}{c}\text { Tax } \\
\text { prescription }\end{array}$ & $\begin{array}{c}\text { Yield } \\
\text { without LC }\end{array}$ & $\begin{array}{l}\text { Use of } \\
\text { LC } 2 \\
\end{array}$ & $\begin{array}{c}\text { Use of } \\
\text { LC } 3\end{array}$ & $\begin{array}{r}\text { Use of } \\
\text { LC } 4 \\
\end{array}$ & $\begin{array}{l}\text { Use of } \\
\text { LC } 5\end{array}$ \\
\hline A & $1,914,823$ & $1,914,823$ & $1,914,823$ & $1,914,823$ & $1,914,823$ & $1,914,823$ \\
\hline B & 104,048 & 104,048 & 104,048 & 104,048 & 104,048 & 104,048 \\
\hline $\mathrm{C}$ & 197,349 & 197,332 & 394,664 & 591,996 & 789,328 & 986,659 \\
\hline $\mathrm{D}$ & 1,347 & 1,330 & 2,661 & 3,991 & 5,322 & 6,652 \\
\hline E & 118,030 & 116,545 & 233,090 & 349,635 & 466,180 & 582,725 \\
\hline$F$ & 71,948 & 71,043 & 142,085 & 213,128 & 284,171 & 355,214 \\
\hline G & 547,510 & 540,619 & $1,081,238$ & $1,621,858$ & $2,162,477$ & $2,703,096$ \\
\hline$X$ & 45,420 & 44,848 & 89,697 & 134,545 & 179,393 & 224,242 \\
\hline Y & 856,000 & 845,228 & $1,690,455$ & $2,535,683$ & $3,380,910$ & $4,226,138$ \\
\hline $\mathrm{H}$ & $1,442,666$ & $1,424,510$ & $2,849,020$ & $4,273,529$ & $5,698,039$ & $7,122,549$ \\
\hline I & 209,629 & 206,991 & 413,982 & 620,973 & 827,964 & $1,034,954$ \\
\hline $\mathrm{J}$ & 243,732 & 240,665 & 481,330 & 721,995 & 962,660 & $1,203,326$ \\
\hline K & 18,950 & 18,712 & 37,423 & 56,135 & 74,847 & 93,559 \\
\hline $\mathrm{L}$ & 247,283 & 244,171 & 488,341 & 732,512 & 976,683 & $1,220,854$ \\
\hline $\mathrm{M}, \mathrm{N}, \mathrm{O}$ & $3,393,449$ & $3,350,742$ & $6,701,484$ & $10,052,227$ & $13,402,969$ & $16,753,711$ \\
\hline $\mathrm{P}$ & 126,180 & 124,592 & 249,185 & 373,777 & 498,369 & 622,961 \\
\hline $\mathrm{R}$ & $1,082,650$ & $1,069,025$ & $2,138,050$ & $3,207,076$ & $4,276,101$ & $5,345,126$ \\
\hline $\mathrm{S}, \mathrm{T}, \mathrm{U}$ & 86,585 & 85,495 & 170,991 & 256,486 & 341,982 & 427,477 \\
\hline V & 53,183 & 52,514 & 105,028 & 157,542 & 210,057 & 262,571 \\
\hline Z & 11,216 & 11,075 & ,22,149 & 33,224 & 44,299 & 55,374 \\
\hline Overall & $10,772,000$ & $10,664,308$ & $19,309,746$ & $27,955,183$ & $36,600,621$ & $45,246,058$ \\
\hline
\end{tabular}

Potential real estate tax revenues were also determined for model cases where all municipalities in the Czech Republic would set C 1.5 and at the same time LC. The potential was determined for all values of the local coefficient. The maximum real estate tax revenue in the case of the use of C 1.5 in combination with LC 5 would amount to more than CZK 62 billion (Table 6). 
COEFFICIENTS OF REAL ESTATE TAX

Table 6. Model 3: Potential tax revenue for 2018, if municipalities use a coefficient of 1.5 and a local coefficient (ths. CZK), own calculation

\begin{tabular}{|c|c|c|c|c|c|c|}
\hline $\begin{array}{c}\text { Type of real } \\
\text { estate }\end{array}$ & $\begin{array}{c}\text { Tax } \\
\text { prescription }\end{array}$ & $\begin{array}{c}\text { Without } \\
\text { LC a C } 1.5\end{array}$ & $\begin{array}{c}\text { Combination } \\
\text { of uses LC } 2 \\
\text { and C } 1.5 \\
\end{array}$ & $\begin{array}{c}\text { Combination } \\
\text { of uses LC } 3 \\
\text { and C } 1.5 \\
\end{array}$ & $\begin{array}{c}\text { Combination } \\
\text { of uses LC } 4 \\
\text { and C } 1.5 \\
\end{array}$ & $\begin{array}{c}\text { Combination } \\
\text { of uses LC } 5 \\
\text { and C } 1.5\end{array}$ \\
\hline A & $1,914,823$ & $1,914,823$ & $1,914,823$ & $1,914,823$ & $1,914,823$ & $1,914,823$ \\
\hline B & 104,048 & 104,048 & 104,048 & 104,048 & 104,048 & 104,048 \\
\hline $\mathrm{C}$ & 197,349 & 197,332 & 394,664 & 591,996 & 789,328 & 986,660 \\
\hline $\mathrm{D}$ & 1,347 & 1,330 & 2,660 & 3,990 & 5,320 & 6,650 \\
\hline $\mathrm{E}$ & 118,030 & 116,545 & 233,090 & 349,635 & 466,180 & 582,725 \\
\hline $\mathrm{F}$ & 71,948 & 71,043 & 142,086 & 213,129 & 284,172 & 355,215 \\
\hline G & 547,510 & 540,619 & $1,081,238$ & $1,621,857$ & $2,162,476$ & $2,703,095$ \\
\hline$X$ & 45,420 & 44,848 & 89,696 & 134,544 & 179,392 & 224,240 \\
\hline $\mathrm{Y}$ & 856,000 & 845,228 & $1,690,456$ & $2,535,684$ & $3,380,912$ & $4,226,140$ \\
\hline $\mathrm{H}$ & $1,442,666$ & $1,424,510$ & $2,849,020$ & $4,273,530$ & $5,698,040$ & $7,122,550$ \\
\hline I & 209,629 & 206,991 & 620,973 & 620,973 & $1,241,946$ & $1,552,432$ \\
\hline $\mathrm{J}$ & 243,732 & 201,695 & 605,085 & 907,628 & $1,210,170$ & $1,512,713$ \\
\hline $\mathrm{K}$ & 18,950 & 15,680 & 47,040 & 70,560 & 94,080 & 117,600 \\
\hline $\mathrm{L}$ & 247,283 & 225,157 & 675,469 & $1,013,204$ & $1,350,939$ & $1,688,673$ \\
\hline $\mathrm{M}-\mathrm{O}$ & $3,393,449$ & $2,410,164$ & $7,230,492$ & $10,845,738$ & $14,460,984$ & $27,114,345$ \\
\hline $\mathrm{P}$ & 126,180 & 126,180 & 252,360 & 757,080 & 504,720 & 630,900 \\
\hline $\mathrm{R}$ & $1,082,650$ & $1,069,025$ & $2,138,050$ & $3,207,075$ & $4,276,100$ & $5,345,125$ \\
\hline S-U & 86,585 & 68,354 & 205,062 & 307,593 & 410,124 & 768,982 \\
\hline $\mathrm{V}$ & 453,183 & 452,670 & $1,358,010$ & $2,037,015$ & $2,716,020$ & $5,092,537$ \\
\hline Z & 11,216 & 11,075 & 22,150 & 33,225 & 44,300 & 55,375 \\
\hline Overall & $10,772,000$ & $10,047,317$ & $21,656,473$ & $31,543,327$ & $41,294,074$ & $62,104,830$ \\
\hline
\end{tabular}

The share of real estate tax in the tax and total revenues of municipalities would increase depending on the application of specific coefficients. If all municipalities in the Czech Republic set C 1.5 for all buildings and units and at the same time set LC 5, the share of tax revenues would be $22.32 \%$ instead of the original $4.76 \%$ (Table 7 ).

Table 7. Share of prescribed tax and potential revenues when introducing coefficients on tax and total revenues of municipalities for 2018, own calculation

\begin{tabular}{|c|c|c|c|c|c|}
\hline & $\begin{array}{c}\text { Prescribed } \\
\text { tax }\end{array}$ & $\begin{array}{c}\text { Combination of } \\
\text { uses } \\
\text { LC 2 and C 1.5 }\end{array}$ & $\begin{array}{c}\text { Combination } \\
\text { of uses } \\
\text { LC 3 and C 1.5 }\end{array}$ & $\begin{array}{c}\text { Combination } \\
\text { of uses } \\
\text { LC 4 andnd } \\
\text { C 1.5 }\end{array}$ & $\begin{array}{c}\text { Combination } \\
\text { of uses } \\
\text { LC 5 a C 1.5 }\end{array}$ \\
\hline $\begin{array}{c}\text { Share of tax revenue of } \\
\text { municipalities in the } \\
\text { Czech Republic }\end{array}$ & $4.76 \%$ & $9.11 \%$ & $12.73 \%$ & $16.04 \%$ & $22.32 \%$ \\
\hline $\begin{array}{c}\text { Share in total revenue } \\
\text { of municipalities in the } \\
\text { Czech Republic }\end{array}$ & $3.26 \%$ & $6.32 \%$ & $8.95 \%$ & $11.40 \%$ & $16.22 \%$ \\
\hline
\end{tabular}




\section{Discussion}

Real estate tax is included among property taxes. Vančurová and Láchová (2016) state that they are of limited importance in the current Czech tax system. The Czech Republic has one of the lowest shares of property tax revenue in total tax revenues from EU countries, and the Czech Republic is criticized for this by the OECD (Janoušková \& Sobotovičová, 2016).

These statements can also be supported by the analyzes performed. Real estate tax revenue in 2018 represented a share of $1.2 \%$ in the total collection of collected taxes in the Czech Republic. The share of real estate tax revenue in the total collection of collected taxes in the Czech Republic over the last 15 years ranged between 0.68-1.63\%. According to Almy (2014), real estate tax generally accounts for a small share of total tax revenues as well

as GDP, both in the first world and in developing countries. The share of the revenue from all property taxes in the total GDP in the Czech Republic in 2018 was $0.5 \%$. The average of OECD countries for this indicator is $1.9 \%$. The share of real estate tax in GDP was only $0.2 \%$.

Real estate tax revenues in the Czech Republic are the income of municipalities. The situation is similar in other countries. According to Norregaard (2013), real estate tax revenues belong to local governments and make a significant contribution to their financing. Income from this tax was the fourth highest of all tax revenues for municipalities in the Czech Republic in 2018, but it accounted for only 3.4\% of total municipal tax revenues. The analyzes of real estate tax revenues in the context of the use of its potential show that municipalities use the possibility of increasing or setting coefficients to a very limited extent. Thus, municipalities limit their revenues from this tax. If all municipalities used at least LC 2 in 2018, the tax revenue would be 1.8 times the actual revenue. If the analyzed coefficients were used in full, the potential yield would be 5.8 times the original yield. Municipalities have the power to significantly increase their real estate tax revenues, but this power is used only to a limited extent. In the period 2016 to 2018, the number of municipalities that used C1.5 increased only in cases where this coefficient was determined, namely for buildings and units used for business $(\mathrm{M}, \mathrm{N}, \mathrm{O}, \mathrm{S}, \mathrm{T}, \mathrm{U})$ and for units used as a garage $(\mathrm{V})$. In the above period, the number of municipalities that set LC 2 or LC 3 increased. In the case of using LC 4, the number of municipalities that used this coefficient decreased between 2017 and 2018.

\section{Conclusions}

In the Czech Republic, the real estate tax is an exclusive tax in terms of municipal budgets and its revenues flow into the municipal budget. It is the only tax for which the municipality can influence the income by adjusting or setting coefficients that increase the rate, or by a local coefficient by which the calculated tax is multiplied.

The analyzes show that the increase in the rate using C 1.5 was used by municipalities mainly for type J and $\mathrm{K}$ constructions. In 2018, it was more than $24 \%$ of municipalities. For other types of buildings and units, this coefficient was used less frequently. Only $8-14 \%$ of municipalities out of their total number used it for various types of buildings and units. In 2018, only 608 municipalities used the increase in real estate tax revenue through the local coefficient, ie. $9.72 \%$ of the total number of municipalities in the Czech Republic. 
Calculations of yield potentials using individual coefficients were performed for the model year 2018. Input data on revenues from individual types of real estate were adjusted for the effect of coefficients, which were determined for this year in individual municipalities. The use of $C 1.5$ would mean an increase in real estate tax revenue in a given year by more than CZK 1 billion. Another model calculation was performed in case of determining only the local coefficient. In this case, the potential for revenue was set at CZK 45.25 billion, which would mean an increase in revenue by CZK 34.7 billion. The yield potential was also determined for a combination of the use of coefficients. The maximum potential yield in the model year 2018 would be CZK 62.1 billion with the combination of C1.5 and LC 5. The share of real estate tax revenue in tax revenues would increase from $4.76 \%$ to $22.32 \%$.

Acknowledgments: This paper is a partial result of the research project No. 2019 B0010 - Czech Social System Fraud Rate Estimation and System Optimization Proposals, supported by the Internal Grant Agency (IGA) of Faculty of Economics and Management, CULS Prague.

\section{References}

Act. no 338/1992. On real estate tax. Czech Republic. The Parliament of The Czech Republic. https://www.zakonyprolidi.cz/cs/1992-338

Almy, R. (2014). Valuation and Assessment of Immovable Property (OECD Working Papers on Fiscal Federalism No. 19). OECD. https://doi.org/10.1787/22265848

Bečica, J. (2014). Czech Municipalities and Real Estate Tax. In 19th International Conference: Theoretical and Practical Aspects of Public Finance 2014 (pp. 19-27). Praha, Czech Republic.

Blazic, H., Simovic, H., \& Stambuk, A. (2016). Introduction of a Local Real Estate Tax in Croatia: A Survey of Expert and Public Opinion. Lex Localis-Journal of Local Self-Government, 14(1), 53-74. https://doi.org/10.4335/14.1.53-74

Cammeraat, E., \& Crivelli, E. (2020). Justifiably unpopular? The Italian property tax and inequality. Applied Economics Letters. https://doi.org /10.1080/13504851.2020.1827129

Czech Statistical Office. (2020). Př́jmy územních rozpočtů (Revenue of local budgets) [Data set]. Retrieved July 18, 2020 from https://vdb.czso.cz/vdbvo2/faces/cs/index.jsf?page=vystupbjekt\&pvo=FIN02\&z=T\&f=TABULKA\&katalog =30830\&str=v26\&u=v4_VUZEMI_97__19

Drabek, K. (2015). Identification of the Urban Municipalities of the Malopolska Region in Terms of Changes in the Real Estate Tax Rates in Business Activities of Enterprises in the Period 2010-2015. In A. Nalepka, \& A. Ujwary-Gil, (Eds.), Proceedings of the 4th Conference on Business and Non-Profit Organizations Facing Increased Competition and Growing Customers' Demands (pp. 223-232). https://hdl.handle.net/11199/8965

Financial Administratin of the Czech Republic. (2019). Daň z nemovitých věcí (Real estate tax) [Data set]. Financial Administratin of the Czech Republic, ADIS. Retrieved July 27, 2020 from https://www.financnisprava.cz/cs/dane/analyzy-a-statistiky/danova-statistika

Huang, Y. (2018). Design of the Elements of Real Estate Tax on Possession from Real Estate Tax in the UK. In R. Green, I. Solovjeva, Y. Zhang, R. Hou, \& E. McAnally (Eds.), Proceedings of the 3rd International Conference on Judicial, Administrative and Humanitarian Problems of State Structures and Economic Subjects (JAHP) (pp. 150-154). https://doi.org/10.2991/jahp-18.2018.31

Janouskova, J., \& Sobotovičova, Š. (2016). Immovable property tax in the Czech Republic as an instrument of fiscal decentralization. Technological and Economic Development of Economy, 22(6), 767-782. https://doi.org/10.3846/20294913.2016.1236355

Janouskova, J., \& Sobotovičova, Š. (2017). Local Coefficient as a Tool to Increase Revenues from Taxes on Immovable Property. In V. Klimova, \& V. Zitek (Eds.), Proceedings of 20th International Colloquium on Regional Sciences (pp. 848-854). Masaryk University. https://doi.org/10.5817/CZ.MUNI.P210-8587-2017-111

Janouskova, J., \& Sobotovičova, Š. (2019). Fiscal autonomy of municipalities in the context of land taxation in the Czech Republic. Land Use Policy, 82, 30-36. https: //doi.org/10.1016/j.landusepol.2018.11.048 
Malkowska, A., Gluszak, M., Marona, B., \& Telega, A. (2020). The Impact of the Electoral Cycle on Area-Based Property Tax in Poland. Eastern European Economics, 58(6), 517-535. https://doi.org/10.1080/00128775.2020.1798160

Kukalová, G., Ječmínek, J., Moravec, L., \& Bína Filipová, D. (2019). Municipal Finance Education Results at FEM CULS Prague Appraisal. In J. Fejfar, M. Fejfarova, M. Flegl, J. Husak, \& I. Krejci (Eds.), Proceedings of the 16th International Conference on Efficiency and Responsibility in Education (ERIE) (pp. 146-153). Czech University of Life Sciences. https://erie.v2.czu.cz/en/r-14822-proceedings-2019

Moravec, L., \& Kukalová, G. (2014). Investments Allocation Tax Factors in Pre-crisis Time. In O. Deey, V. Kajurova, \& J. Krajicek (Eds.), Proceedings of the 11th International Scientific Conference on European Financial systems 2014 (pp. 396-402). Masaryk University. https://is.muni.cz/do/econ/sborniky/2014/proceedings-EFS-2014.pdf

Norregaard, J. (2013). Taxing Immovable Property Revenue Potential and Implementation Challenges (IMF Working Papers No. 13). IMF. https://doi.org/10.5089/9781484369050.001

Olejniczak, J., Bednarska-Olejniczak, D., Maci, J., \& Svobodova, L. (2020). Real Property Tax in Polish Communes of the Polish-Czech Border Region. In P. Jedlicka, P. Maresova, K. Firlej, \& I. Soukal (Eds.), Proceedings of the International Scientific Conference on Hradec Economic Days 2020 (HED) (pp. 565-573). University of Hradec Králové. https://doi.org/10.36689/uhk/hed/2020-01-032

Pfeiferová, D., Ulrych, M., Kuchařová, I., \& Kozlová, H. (2020). In P. Jedlicka, P. Maresova, K. Firlej, \& I. Soukal (Eds.), Proceedings of the International Scientific Conference on Hradec Economic Days 2020 (HED) (pp. 598-605). University Hradec Kralove. https://doi.org/10.36689/uhk/hed/2020-01-068

Sedmihradská, L., \& Bakoš, E. (2016). Municipal Tax Autonomy and Tax Mimicking in Czech Municipalities. Lex Localis-Journal of Local Self-Government, 14(1), 75-92. https://doi.org /10.4335/14.1.75-92(2016)

Vančurová, A., \& Láchová, L. (2016). Daňový systém ČR (Tax system of the Czech Republic) (13th ed). VOX.

Zróbek S., Manzhynski S., Zysk E., \& Rassokha, Y. (2016). Some aspects of local real estate taxes as an instrument of land use management. Real Estate Management and Valuation, 24(3), 93-105. https://doi.org/10.1515/remav-2016-0024 